\title{
The frequency of HLA-DR alleles in patients with tick-borne disease from Latvia
}

Lilija Kovalchuka ${ }^{*}$, Jelena Eglite' ${ }^{1}$, Mara Zalite ${ }^{2,3}$, Irina Lucenko ${ }^{4}$, Inara Logina ${ }^{5}$, Guntis Karelis ${ }^{5}$, Ludmila Viksna ${ }^{2,3}$ and Angelika Krumina ${ }^{2}$

*Correspondence: Lilija.Kovalcuka@rsu.Iv

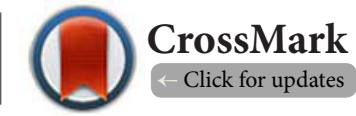

'Laboratory of Clinical Immunology and Immunogenetics, Riga Stradins University, Riga, Latvia.

${ }^{2}$ Department of Infectology and Dermatology, Riga Stradins University, Riga, Latvia.

${ }^{3}$ Department of Infectology and Dermatology, Infectology Center of Latvia, Riga Stradins University, Riga, Latvia.

${ }^{4}$ Centre for Disease Prevention and Control, Riga, Latvia.

${ }^{5}$ Department of Neurology and Neurosurgery, Riga Stradins University, Riga, Latvia.

\begin{abstract}
Background: The level of incidence of Tick-borne disease in Latvia still is one of the highest in Europe. There are some similarities between the viral agents, and HLA molecules, because in organism develops one way or another immune response to infection. Clarifying the polymorphisms of HLA molecules will allow to identify regularities of pathological process and to develop a new approach to treating these diseases.
\end{abstract}

The purpose: Of this study was to determine HLA-DR alleles in two groups Latvian patients: in patients with Lyme borreliosis (LB) and patients with Tick-borne encephalitis (TBE). The study included 38 patients with clinical stage -erythema migrans, 60 patients with TBE and 100 control (healthy) persons. All patients and healthy persons are residents of Latvia. HLA genotyping was performed by PCR with sequence-specific primers.

Results: The frequency of HLA-DRB1*17(03) (odds ratio, 4.06; pc=0.003), HLA-DRB1*04 (odds ratio, 3.22; $\mathrm{pc}=0.162$ ), and HLA-DRB1*13 (odds ratio, 2.37; $\mathrm{pc}=0.055)$, were higher in patients with LB. And the HLA-DRB1*10 (odds ratio, 0.16 ; pc=0.044) was smaller in LB patients and significantly higher in controls. Among TBE patients the HLA-DRB1*04 (11 percent vs. 5 percent; odds ratio, 2.58; pc $=0.386$ ) and DRB1*17(03) (10 percent vs. 4 percent; odds ratio, 2.67; pc=0.396) alleles were increased, but the HLADRB1*01 (2 percent vs. 6 percent; odds ratio, 0.13 ; pc $=0.240$ ) was lower in patients, these differences were not significant after Bonferroni correction.

Conclusions: These data suggest the positive association of HLA-DRB1*17(03) allele with Lyme borreliosis in Latvian patients, and HLA-DRB1*10 allele could be associated with a potential protective effect. Among TBE patients statistically significant associations of HLA-DRB1 not detected.

Keywords: Tick-borne diseases, HLA alleles, marker, PCR

\section{Background}

Today ticks inhabit almost every continent, with the number of species worldwide topping 850 [1-4]. The recognized number of important diseases transmitted by ticks has been growing over the past 30 years $[4,10,11]$.

Lyme disease is a debilitating infection transmitted via the bite of ticks infected with Borrelia burgdorferi (Bb). One of the most prominent clinical manifestations of Lyme disease is the development of chronic Lyme arthritis [12-15]. Some patients continue to experience persistent joint inflammation despite antibiotic treatment, a condition referred to as antibioticrefractory Lyme arthritis [13-15]. This inflammatory response is characterized by proliferative synovitis, and it may persist for months or even several years. One of the factors that confer susceptibility to antibiotic-refractory Lyme arthritis is the presence of certain HLA-DR alleles $[16,19,20]$. Patients presenting with joint inflammation after antibiotic therapy have a higher frequency of HLA-DRB1*0401 (DR4) $[16,17]$. 
While the idea of HLA-related genes being involved in the control of the clinical progression of Lyme arthritis is well documented [17], the possible role of the HLA region in susceptibility to disease per se has also been suggested $[18,21]$. Some results have already been found for class I HLA alleles [19], however a greater number of studies have reported increased frequencies of class II alleles in Lyme arthritis patients in several populations $[16,17,20]$.

Tick-borne encephalitis is an infection caused by viruses, and the diseases mainly affects the central nervous system of the man. Damage to the central nervous system may have different symptoms in each specific case: from moderate meningitis to very severe cases of meningoencephalitis, meningoencephaloielitis. The incidence of Tick-borne disease in Latvia is one of the highest in Europe $[10,22]$. The prevalence of Tick-borne encephalitis virus in 2012 exceeded 10\%, while in 2011 it was $5.7 \%$ and $4.1 \%$ in 2010 [10].

In the present study, we investigate the HLA DR alleles in two group's patients: patients with Lyme borreliosis and patients with tick-borne encephalitis. The aim of the investigation was to identify risk alleles and protective alleles in Latvian patients. For this examinations, MHC classes II alleles was performed by PCR Low-resolution HLA-DR typing. The obtained data were compared with the control group of healthy individuals. The results of comparisons were assessed by Chi square test, Bonferroni test, and Fisher's Exact Test (when necessary).

\section{Materials and methods}

\section{Characteristic of the studied patients}

The study included 38 patients with clinical stage-erythema migrans, 60 patients with tick-borne encephalitis and 100 control (healthy) persons. The included patients' ages ranged from 18 and 62 years of age. The majority of patients were between $22-45$ years of age, representing $60.4 \%$ of the total studied. All patients and healthy persons are residents of Latvia. The clinical diagnosis was confirmed at Infectology Center of Latvia. Immunogenetic examinations were performed in Riga Stradiņš University, laboratory of Clinical Immunology and Immunogenetics. The Riga Stradinš University Ethics Committee approval was obtained. And the written informed consent for participation in the study from participants was obtained.

\section{HLA-typing}

Blood samples $(5 \mathrm{~mL})$ were collected from the subjects in tubes containing anticoagulant (EDTA) and centrifuged at 2,500 rpm for 15 minutes, and the Buffy-coat was conserved at $-20^{\circ} \mathrm{C}$ until use. The genomic DNA was extracted from proteinase-K-treated peripheral blood leukocytes using the routine "salting-out" method $[\mathbf{2 4 , 2 5 ]}$. The DNA was stored in TE buffer ( $10 \mathrm{ml}$ Tris- $\mathrm{HCl}, \mathrm{pH} 7.5$, and $2 \mathrm{ml} 0.5 \mathrm{M} \mathrm{Na} 2$ EDTA per liter of distilled water). The DNA concentration, around 100-200 $\mu \mathrm{g} /$ $\mathrm{ml}$, was determined by fluorescence with a DNA fluorimeter. HLA-DR genotyping by PCR Low-resolution for DRB $1 * 01$ to DRB1*18; was performed by PCR with sequence-specific prim- ers (PCR-SSP) $[\mathbf{2 4 , 2 5}]$. The reaction mixture $(15 \mu \mathrm{l})$ included $1.0 \mu \mathrm{l} \mathrm{DNA}, 1.5 \mu \mathrm{l}$ PCR buffer $[50 \mathrm{mM} \mathrm{KCl}, 1.5 \mathrm{mM} \mathrm{MgCl} 2,10 \mathrm{mM}$ Tris- $\mathrm{HCl}(\mathrm{pH} 8.3)], 0.6 \mu \mathrm{l}$ dNTPs $(25 \mathrm{mmol} / \mathrm{l}), 1.0 \mu \mathrm{l}$ specific primers $(0.2 \mathrm{mmol} / \mathrm{l})$, and $0.5 \mathrm{U}$ of the Taq DNA polymerase (Promega). The reaction mixture was subjected to $35 \mathrm{ampli}$ fication cycles, each consisting of one denaturation cycle at $94^{\circ} \mathrm{C}(60 \mathrm{~s})$, seven annealing cycles at $94^{\circ} \mathrm{C}(40 \mathrm{~s})$ and $67^{\circ} \mathrm{C}(15$ s), and final 28 extension cycles at $93^{\circ} \mathrm{C}(10 \mathrm{~s})$ and $65^{\circ} \mathrm{C}(9 \mathrm{~s})$. PCR products were visualized by agarose-gel electrophoresis $[24,25]$. After addition of $2 \mathrm{M}$ loading buffer, the PCR reaction mixtures were loaded in agarose gels prestained with ethidium bromide $(0.5 \mu \mathrm{k} / \mathrm{ml}$ gel). Gels were run for $15 \mathrm{~min}$ at $10 \mathrm{~V} / \mathrm{cm}$ gel in 0.5mM TBE (0.89 M Tris, $0.89 \mathrm{M}$ Boric acid and $0.02 \mathrm{M}$ EDTA in aqueous solution) buffer and then examined under UV illumination and recorded [25].

\section{Statistical analysis}

The significance of differences in individual subtypes between patients and controls was performed using the Chi square test, with the Bonferroni correction or Fisher's Exact Test when necessary [26]. Data were considered statistically significant when the $P$ value was less than or equal to 0.05 . However, to account for multiple comparisons, the observed $P$ values were corrected ( $p c)$ for the number of alleles when one locus was considered alone. The odds ratios (OR), with $95 \%$ confidence intervals $(95 \% \mathrm{CI})$, were calculated using SISA statistics online http://home.clara.net/sisa/, to evaluate the risk of the individual developing the disease while having a particular HLA type.

\section{Results}

The frequency of DRB 1 * alleles of the LB patients and control group are shown in Table 1. There were differences between LB patients and the control group for HLA-DRB1*17(03) (15 percent vs. 4 percent; odds ratio, 4.06; $p=0.002$ ) and HLA-DRB1 ${ }^{*} 04$ ( 13 percent vs. 5 percent; odds ratio, 3.22; $p=0.011$ ), which appeared with greater frequency in the patients. We also detected a difference for HLA-DR* 13 . The frequency of allele DRB1*13 (13 percent vs. 6 percent; odds ratio, $2.37 ; p=0.049$ ) was higher in Borreliosis patients and lower in controls (Table 1). In contrast, HLA-DRB $1 * 10$ ( 2 percent vs. 8 percent; odds ratio, $0.16 ; p=0.036$ ) frequencies were lower in LB patients (Table 1 ).

The frequency of DRB $1^{*}$ alleles of the TBE patients and control group are shown in Table 2. Among TBE patients the DRB $1 * 04$ ( 11 percent vs. 5 percent; odds ratio, $2.58 ; p=0.03$ ) and DRB1*17(03) (10 percent vs. 4 percent; odds ratio, 2.67; $\mathrm{p}=0.031$ ) alleles, had the greatest frequency. While DRB $1{ }^{*} 01$ frequency was lower (1 percent vs. 6 percent; odds ratio, 0.13; $\mathrm{p}=0.017$ ) in these patients (Table 2).

Of interest, all 10 patients with Lyme borreliosis who had HLA-DRB 1*04 were heterozygous at the DR locus. Four had HLA-DRB $1{ }^{*} 04$ and HLA-DRB $1 * 17(03)$, two had HLA-DRB1 *04 and HLA-DRB1* 15 , one had HLA-DRB1*04 and HLA-DRB1* 18(03), and one HLA-DRB $1 * 04$ and HLA-DRB1*11.

Of the 13 patients with TBE who had HLA-DRB $1 * 04$, only 
Table 1. The frequency of DRB1* alleles studied in-patients with LB and healthy controls from Latvia.

\begin{tabular}{|c|c|c|c|c|c|}
\hline Allele DRB1 & $\begin{array}{l}\text { Patients }(n=38) \\
76 \text { alleles }\end{array}$ & $\begin{array}{l}\text { Controls }(n=100) \\
200 \text { alleles }\end{array}$ & OR $(95 \% \mathrm{CI})$ & p-value & pc-value \\
\hline *01 & $2(3 \%)$ & $12(6 \%)$ & $0.42(0.06-2.07)$ & 0.207 & -- \\
\hline${ }^{\star} 02$ & $2(3 \%)$ & $12(6 \%)$ & $0.42(0.06-2.07)$ & 0.207 & -- \\
\hline${ }^{\star} 03$ & $3(4 \%)$ & $9(5 \%)$ & $0.87(0.18-3.65)$ & 0.569 & -- \\
\hline${ }^{\star} 04$ & $10(13 \%)$ & $9(5 \%)$ & $3.22(1.15-9.07)$ & 0.011 & 0.162 \\
\hline${ }^{\star} 07$ & $3(4 \%)$ & $15(8 \%)$ & $0.51(0.11-1.94)$ & 0.217 & -- \\
\hline${ }^{\star} 08$ & $2(3 \%)$ & $10(5 \%)$ & $0.51(0.08-2.58)$ & 0.311 & -- \\
\hline *09 & $2(3 \%)$ & $16(8 \%)$ & $0.31(0.05-1.46)$ & 0.083 & -- \\
\hline${ }^{\star} 10$ & $1(2 \%)$ & $15(8 \%)$ & $\mathbf{0 . 1 6}(0.01-1.22)$ & 0.036 & 0.044 \\
\hline *11 & $8(11 \%)$ & $21(11 \%)$ & $1.00(0.39-2.53)$ & 0.831 & -- \\
\hline *12 & $4(6 \%)$ & $17(9 \%)$ & $0.60(0.16-1.98)$ & 0.364 & -- \\
\hline *13 & $10(13 \%)$ & $12(6 \%)$ & $2.37(0.90-6.23)$ & 0.049 & 0.055 \\
\hline *14 & $6(8 \%)$ & $13(7 \%)$ & $1.23(0.40-3.66)$ & 0.682 & -- \\
\hline *15 & $4(6 \%)$ & $12(6 \%)$ & $1.87(0.23-3.04)$ & 0.537 & -- \\
\hline *16 & $2(3 \%)$ & $11(6 \%)$ & $0.46(0.07-2.30)$ & 0.255 & -- \\
\hline${ }^{\star} 17(03)$ & $11(15 \%)$ & $8(4 \%)$ & $4.06(1.44-11.65)$ & 0.002 & 0.003 \\
\hline${ }^{\star} 18(03)$ & $6(8 \%)$ & $8(4 \%)$ & $2.06(0.61-6.83)$ & 0.155 & -- \\
\hline
\end{tabular}

Abbreviations: OR: Odds ratio; CI: Confidence interval; p-value: Probability; pc-value (after Bonferroni adjustment)

Table 2. The frequency of DRB1* alleles studied in-patients with TBE and healthy controls from Latvia.

\begin{tabular}{|c|c|c|c|c|c|}
\hline Allele DRB1 & $\begin{array}{l}\text { Patients }(n=60) \\
120 \text { alleles }\end{array}$ & $\begin{array}{l}\text { Controls }(n=100) \\
200 \text { alleles }\end{array}$ & OR (95\% CI) & p-value & pc-value \\
\hline${ }^{\star} 01$ & $1(2 \%)$ & $12(6 \%)$ & $\mathbf{0 . 1 3}(0.01-0.99)$ & 0.017 & 0.240 \\
\hline *02 & $8(7 \%)$ & $12(6 \%)$ & $1.12(0.40-3.05)$ & 0.811 & -- \\
\hline *03 & $5(4 \%)$ & $9(5 \%)$ & $0.92(0.26-3.11)$ & 0.887 & -- \\
\hline${ }^{*} 04$ & $13(11 \%)$ & $9(5 \%)$ & $2.58(0.99-6.80)$ & 0.030 & 0.386 \\
\hline$\star 07$ & $7(6 \%)$ & $15(8 \%)$ & $0.76(0.27-2.07)$ & 0.568 & -- \\
\hline${ }^{*} 08$ & $4(4 \%)$ & $10(5 \%)$ & $0.66(0.17-2.34)$ & 0.480 & -- \\
\hline *09 & $9(8 \%)$ & $16(8 \%)$ & $0.93(0.37-2.33)$ & 0.871 & -- \\
\hline${ }^{\star} 10$ & $8(7 \%)$ & $15(8 \%)$ & $0.88(0.33-2.30)$ & 0.779 & -- \\
\hline *11 & $8(7 \%)$ & $21(11 \%)$ & $0.61(0.24-1.51)$ & 0.247 & -- \\
\hline *12 & $9(8 \%)$ & $17(9 \%)$ & $0.87(0.35-2.16)$ & 0.751 & -- \\
\hline *13 & $6(5 \%)$ & $12(6 \%)$ & $0.82(0.27-2.45)$ & 0.707 & -- \\
\hline ^14 & $9(8 \%)$ & $13(7 \%)$ & $1.17(0.44-3.03)$ & 0.732 & -- \\
\hline *15 & $2(2 \%)$ & $12(6 \%)$ & $0.27(0.04-1.28)$ & 0.066 & -- \\
\hline${ }^{\star} 16$ & $8(7 \%)$ & $11(6 \%)$ & $1.23(0.44-3.41)$ & 0.668 & -- \\
\hline${ }^{\star} 17(03)$ & $12(10 \%)$ & $8(4 \%)$ & $2.67(0.98-7.40)$ & 0.031 & 0.396 \\
\hline${ }^{\star} 18(03)$ & $11(9 \%)$ & $8(4 \%)$ & $2.42(0.87-6.83)$ & 0.058 & -- \\
\hline
\end{tabular}

Abbreviations: OR: Odds ratio; CI: Confidence interval; p-value: Probability; pc-value (after Bonferroni adjustment)

two were homozygous and had severe meningoencephalitis. The other 11 patients were heterozygous at the DR locus. Four had HLA-DRB1*04 and HLA-DRB1*18(03), three had HLA-DRB1 *04 and HLA-DRB1*17(03) and remaining had HLA-DRB1*04 in association with a different DR alleles. A secondary association was noted with the HLA-DRB1*17(03) allele. This allele was found in 15 percent of the patients with Lyme borreliosis and in 10 percent of the patients with TBE, but in only 
Kovalchuka et al. Research Journal of Infectious Diseases 2014,

4 percent in controls group (Tables 1 and 2). The frequency of HLA-DRB1*17(03) allele was significantly higher among LB patients comparing with the control group, than among TBE (odds ratio, 4.06; $p=0.002$ and odds ratio, 2.67; $p=0.031$, respectively) (Tables 1 and 2 ).

Also, the frequency of HLA-DRB1*18(03) tended to be higher among Lyme borreliosis and TBE patients ( 8 and 9 percent vs. 4 percent; odds ratio, 2.06 and 2.42 , respectively) but this difference was not statistically significant (Tables 1 and 2).

In contrast, the allele DRB $1 * 10$ (odds ratio, $0.16 ; p=0.036$ ) was smaller in Lyme borreliosis patients and significantly higher in controls (Table 1). And a different allele - DRB $1 * 01$ (odds ratio, $0.13 ; p=0.017$ ) was smaller in TBE patients and significantly higher in controls (Table 2).

The second step, $p$ values of all detected alleles were exposed to Bonferroni correction (pc), and only frequency of HLA-DRB $1{ }^{*} 17(03)$ allele was significantly higher in Latvian patients with Lyme borreliosis, and HLA-DRB1*10 allele was significantly lower in LB patients (Table 1). Among TBE patients all detected HLA-DRB1 differences were not significant after Bonferroni correction (Table 2).

\section{Discussion}

Many studies have tried to identify genetic markers for infectious diseases; some of them have focused on HLA $[4-6,27,28]$. The products of HLA genes interact with surface-specific receptors of T lymphocytes, resulting in activation of the host's immune response. Association of TBD infections with the host's HLA has been partially investigated $[29,30]$. The type and strength of this association differs among distinct populations, as well as among racial and/or ethnic groups [31].

In our HLA study, a strong association was confirmed between Lyme borreliosis and the HLA-DRB1*17(03) (part of the older HLA-DR3). Although, the frequency of HLA-DRB1*04 allele was increased in patients with Lyme borreliosis and Tick-borne encephalitis, but after applying the Bonferroni correction these differences were not significant. Interestingly, the association between Lyme and HLA-DRB1*17(03) was found only in the Latvian population, while the association of HLA-DRB $1{ }^{*} 04$ was confirmed by many authors, in particular Steere A.C. and co-authors $[12,13]$.

One more statistically significant difference was found in patients with Lyme borreliosis. In our study, the frequency of HLA-DRB $1 * 10$ allele was significantly lower in Borreliosis patients compared with the control group. Although, many authors have noted HLA-DRB $1{ }^{*} 11$ allele as a possible protective allele $[6,12,17]$.

These results suggest that the high risk for Tick-borne Disease in Latvian associated with the HLA-DRB1*17(03), and perhaps, HLA-DRB $1 * 04$ alleles. But, the HLA-DRB $1 * 10$ allele seems to have a protective effect in Latvian patients with Lyme borreliosis.

Although this series of 60 patients with Tick-borne encephalitis is the largest tested to date, the number of patients was not large enough to show significant differences between TBE patients and control group in the frequencies of individual alleles.

There are several hypotheses about the HLA/disease association mechanism, and it is possible that this mechanism varies for different diseases. One of the hypotheses attributes a greater or less affinity of HLA for the disease-causing peptide $[6,12,36]$. Thus, the HLA antigens function as receptors for some etiological agents, by facilitating their entry into the cell or by making such entry difficult. Another possibility would be the early intervention of HLA in the thymic selection of lymphocytes, by determining which antigens will be presented to the Tlymphocytes $[\mathbf{2 0}, \mathbf{3 3}, \mathbf{3 7}, \mathbf{3 8}]$. There is also the hypothesis that there may be a mechanism of tolerance of T cells to these pathogens, through molecular mimicking between antigens of the infectious microorganisms and antigens of the host, thus providing susceptibility or protection against these diseases $[32,33]$. We reviewed the main associations of the HLA-DR alleles with Lyme borreliosis and Tick-borne encephalitis.

The HLA alleles vary in ethnically different populations $[2,8,9]$. Studies suggest that the alleles that confer resistance to certain pathogens are prevalent in areas where they cause endemic diseases. Greater resistance to infectious diseases occurs in persons that are heterozygote for specific HLA alleles, because a heterozygous person would have a broader spectrum of peptides to link to the T lymphocytes $[11,13,35]$. These alleles also vary from one disease to another, due to the differences in their pathogenesis [34]. In our study, only two patients with TBE who had HLA-DRB $1 * 04$, were homozygous and had severe meningoencephalitis. The diversity of these results is probably due to environmental influences, in addition, possible differences among ethnic group's populations [9].

Genetic studies of infectious diseases not only help us to gain a better understanding of the pathogenic mechanisms of diseases, they may also help with the development of vaccines.

One of the advantages of polymorphism of the HLA region, apparently to avoid deficiencies in efficient immune response to against a specific infectious agent [34]. Susceptibility to an infectious disease may be due to imperfections in some stages of this system. A person that has a certain combination of HLA alleles that do not link in an appropriate manner to the peptide, or whose HLA-peptide link does not elicit an adequate response from the lymphocytes, will be less apt to resist the invasion of the infectious agent than a person who does not have these deficiencies [34]. In patients in whom HLA provides protection, these genes probably select and stimulate $T$ cells that multiply and eliminate the invading agent, through the production of inflammatory cytokines or by destroying the infected cells themselves [35].

\section{Conclusions}

HLA predisposition to Lyme borreliosis and Tick-borne encephalitis appears not to be limited to HLA-DR, but some alleles 
also have a significant influence. In our study, the HLA-DRB1 *17(03) (odds ratio, 4.06; $\mathrm{pc}=0.003$ ), HLA-DRB1*04 (odds ratio, 3.22; $\mathrm{pc}=0.162$ ), and HLA-DRB ${ }^{*} 13$ (odds ratio, 2.37; $\mathrm{pc}=0.055$ ) alleles contributes significantly to a genetic predisposition Lyme borreliosis in Latvian population, but, the HLA-DRB $1{ }^{*} 10$ allele (odds ratio, 0.16; $p c=0.044$ ) could be associated with a potential protective effect. Among TBE patients the HLA$\mathrm{DRB} 1{ }^{*} 04$ (odds ratio, 2.58; $\mathrm{pc}=0.386$ ) and $\mathrm{DRB} 1 * 17(03)$ (odds ratio, 2.67; $\mathrm{pc}=0.396$ ) alleles were increased, but the HLADRB 1*01 (odds ratio, 0.13; pc $=0.240$ ) was lower in patients, but these differences were not significant after Bonferroni correction.

\section{Competing interests}

The authors declare that they have no competing interests.

Authors' contributions

\begin{tabular}{|l|c|c|c|c|c|c|c|c|}
\hline Authors' contributions & LK & JE & MZ & IL1 & IL2 & GK & LV & AK \\
\hline Research concept and design & -- & -- & -- & -- & -- & -- & -- & $\checkmark$ \\
\hline Collection and/or assembly of data & -- & -- & $\checkmark$ & $\checkmark$ & $\checkmark$ & $\checkmark$ & -- & -- \\
\hline Data analysis and interpretation & $\checkmark$ & -- & -- & -- & -- & -- & -- & -- \\
\hline Writing the article & $\checkmark$ & -- & -- & -- & -- & -- & -- & -- \\
\hline Critical revision of the article & $\checkmark$ & -- & $\checkmark$ & $\checkmark$ & $\checkmark$ & $\checkmark$ & $\checkmark$ & $\checkmark$ \\
\hline Final approval of article & -- & -- & -- & -- & -- & -- & $\checkmark$ & -- \\
\hline Statistical analysis & -- & $\checkmark$ & -- & -- & -- & -- & -- & -- \\
\hline
\end{tabular}

Acknowledgement and funding

This work was supported by Riga Stradinš University grant 09.1604 and the European Social Fund (ESF) project "Support for doctoral study program and scientific degree receiving in Riga Stradinš University, agreement No. 2009/0147/1DP/1.1.2.1.2/09/IPIA/VIAA/009".

\section{Publication history}

Editors: Farzin Roohvand, Pasteur Institute of Iran, Iran. Gyanendra Singh, LSU Health Sciences Center, USA. EIC: Ishtiaq Qadri, King Abdul Aziz University, Saudi Arabia. Received: 15-Jun-2014 Final Revised: 29-Aug-2014 Accepted: 08-Oct-2014 Published: 15-Oct-2014

\section{References}

1. Fraenkel CJ, Garpmo U and Berglund J. Determination of novel Borrelia genospecies in Swedish Ixodes ricinus ticks. J Clin Microbiol. 2002; 40:3308-12. | Article | PubMed Abstract | PubMed Full Text

2. Lyme disease data and statistics. CDC (Centers for Disease Control and Prevention). 2014. | Website

3. Kurtenbach K, De Michelis S, Sewell HS, Etti S, Schafer SM, Hails R, Collares-Pereira M, Santos-Reis M, Hanincova K, Labuda M, Bormane A and Donaghy M. Distinct combinations of Borrelia burgdorferi sensu lato genospecies found in individual questing ticks from Europe. Appl Environ Microbiol. 2001; 67:4926-9. | Article | PubMed Abstract | PubMed Full Text

4. Critical Needs and Gaps in Understanding Prevention, Amelioration, and Resolution of Lyme and Other Tick-Borne Diseases: The Short-Term and Long-Term Outcomes: Workshop Report. | Article

5. Wang $P$ and Hilton $E$. Contribution of HLA alleles in the regulation of antibody production in Lyme disease. Front Biosci. 2001; 6:B10-6. | Article I PubMed
6. Steere AC, Falk B, Drouin EE, Baxter-Lowe LA, Hammer J and Nepom GT. Binding of outer surface protein $A$ and human lymphocyte functionassociated antigen 1 peptides to HLA-DR molecules associated with antibiotic treatment-resistant Lyme arthritis. Arthritis Rheum. 2003; 48:534-40. | Article | PubMed

7. Jones EY, Fugger L, Strominger JL and Siebold C. MHC class II proteins and disease: a structural perspective. Nat Rev Immunol. 2006; 6:271-82. | Article | PubMed

8. Kazuo Yamamoto-Furusho J. [Role of genes of the major histocompatibility complex in infections]. Rev Invest Clin. 2000; 52:4616. I PubMed

9. Probst CM, Bompeixe EP, Pereira NF, de ODMM, Visentainer JE, Tsuneto LT and Petzl-Erler ML. HLA polymorphism and evaluation of European, African, and Amerindian contribution to the white and mulatto populations from Parana, Brazil. Hum Biol. 2000; 72:597-617. | PubMed

10. Statistical data on incidence of infectuious diseases in Latvia

11. Kovalchuka L, Eglite J, Lucenko I, Zalite M, Viksna L and Krumina A. Associations of HLA DR and DQ molecules with Lyme borreliosis in Latvian patients. BMC Res Notes. 2012; 5:438. | Article I PubMed Abstract | PubMed Full Text

12. Steere AC and Glickstein L. Elucidation of Lyme arthritis. Nat Rev Immunol. 2004; 4:143-52. | Article I PubMed

13. Steere AC, Klitz W, Drouin EE, Falk BA, Kwok WW, Nepom GT and BaxterLowe LA. Antibiotic-refractory Lyme arthritis is associated with HLA-DR molecules that bind a Borrelia burgdorferi peptide. J Exp Med. 2006; 203:961-71. | Article | PubMed Abstract | PubMed Full Text

14. Li X, McHugh GA, Damle N, Sikand VK, Glickstein L and Steere AC. Burden and viability of Borrelia burgdorferi in skin and joints of patients with erythema migrans or lyme arthritis. Arthritis Rheum. 2011; 63:2238-47. | Article | PubMed

15. Guerau-de-Arellano M and Huber BT. Development of autoimmunity in Lyme arthritis. Curr Opin Rheumatol. 2002; 14:388-93. | Article | PubMed

16. Fernando MM, Stevens CR, Walsh EC, De Jager PL, Goyette P, Plenge RM, Vyse TJ and Rioux JD. Defining the role of the MHC in autoimmunity: a review and pooled analysis. PLoS Genet. 2008; 4:e1000024. | Article | PubMed Abstract | PubMed Full Text

17. Singh SK and Girschick HJ. Lyme borreliosis: from infection to autoimmunity. Clin Microbiol Infect. 2004; 10:598-614. | Article | PubMed

18. Iliopoulou BP, Alroy J and Huber BT. Persistent arthritis in Borrelia burgdorferi-infected HLA-DR4-positive CD28-negative mice postantibiotic treatment. Arthritis Rheum. 2008; 58:3892-901. | Article | PubMed Abstract | PubMed Full Text

19. Seidel MF, Domene AB and Vetter H. Differential diagnoses of suspected Lyme borreliosis or post-Lyme-disease syndrome. Eur J Clin Microbiol Infect Dis. 2007; 26:611-7. | Article | PubMed

20. Anan'eva LP, Barskova VG, Koneva OA, Ushakova MA, Mach ES, Pushkova OV, Guseva IA, Zakharova MM, Radenska-Lopovok SG, Speranskii Al and Kashnikova LN. [Articular lesions in Ixodes tick-borne borreliosis (Lyme disease)]. Vestn Ross Akad Med Nauk. 2003; 42-7. I PubMed

21. Marrack P, Kappler J and Kotzin BL. Autoimmune disease: why and where it occurs. Nat Med. 2001; 7:899-905. | Article | PubMed

22. Arsa F, Bormane $A$ and Krumina $A$. Tick-borne encephalitis and Lyme borreliosis in Latvia: epidemiological situation in 2007-2009. Abstract book ESCAIDE. Poster No 20100123. 2010; 173.

23. Jones EY, Fugger L, Strominger JL and Siebold C. MHC class II proteins and disease: a structural perspective. Nat Rev Immunol. 2006; 6:271-82. | Article | PubMed

24. Klitz W, Maiers M, Spellman S, Baxter-Lowe LA, Schmeckpeper B, Williams TM and Fernandez-Vina M. New HLA haplotype frequency reference standards: high-resolution and large sample typing of HLA DR-DQ haplotypes in a sample of European Americans. Tissue Antigens. 2003; 62:296-307. | Article | PubMed

25. Olerup O, Aldener A and Fogdell A. HLA-DQB1 and -DQA1 typing by 
Kovalchuka et al. Research Journal of Infectious Diseases 2014,

http://www.hoajonline.com/journals/pdf/2052-5958-2-4.pdf

PCR amplification with sequence-specific primers (PCR-SSP) in 2 hours. Tissue Antigens. 1993; 41:119-34. | Article | PubMed

26. Categorical data analysis using the SAS system.

27. Crandall H, Dunn DM, Ma Y, Wooten RM, Zachary JF, Weis JH, Weiss $\mathrm{RB}$ and Weis JJ. Gene expression profiling reveals unique pathways associated with differential severity of lyme arthritis. J Immunol. 2006; 177:7930-42. | Article | PubMed

28. Carter JD, Espinoza LR, Inman RD, Sneed KB, Ricca LR, Vasey FB, Valeriano J, Stanich JA, Oszust C, Gerard HC and Hudson AP. Combination antibiotics as a treatment for chronic Chlamydia-induced reactive arthritis: a double-blind, placebo-controlled, prospective trial. Arthritis Rheum. 2010; 62:1298-307. | Article | PubMed Abstract | PubMed Full $\underline{\text { Text }}$

29. Sartakova ML, Konekov VI, Chernitsina LQ, Prokofiev VF, Alekseenko S and Korotkova IYU. Detection of the Tick Borne Encephalitis Virus in the Ticks and the Study of HLA Associations with the Tick Borne Encephalitis Onset. Immunogenetics: Advances and Education. 1997; 35:103-104. | Article

30. Kotsch K, Wehling J and Blasczyk R. Sequencing of HLA class II genes based on the conserved diversity of the non-coding regions: sequencing based typing of HLA-DRB genes. Tissue Antigens. 1999; 53:486-97. | Article | PubMed

31. Lee KW, Oh DH, Lee $C$ and Yang SY. Allelic and haplotypic diversity of HLA-A, -B, -C, -DRB1, and -DQB1 genes in the Korean population. Tissue Antigens. 2005; 65:437-47. | Article | PubMed

32. Shin JJ, Glickstein LJ and Steere AC. High levels of inflammatory chemokines and cytokines in joint fluid and synovial tissue throughout the course of antibiotic-refractory lyme arthritis. Arthritis Rheum. 2007; 56:1325-35. | Article | PubMed

33. Klein J and Sato A. The HLA system. Second of two parts. N Engl J Med. 2000; 343:782-6. | Article | PubMed

34. Alves C, Souza T, Meyer I, Toralles MB and Brites C. Immunogenetics and infectious diseases: special reference to the mayor histocompatibility complex. Braz J Infect Dis. 2006; 10:122-31. | Article | PubMed

35. Drouin EE, Glickstein L, Kwok WW, Nepom GT and Steere AC. Searching for borrelial T cell epitopes associated with antibiotic-refractory Lyme arthritis. Mol Immunol. 2008; 45:2323-32. | Article | PubMed Abstract | PubMed Full Text

36. Mangalam AK, Rajagopalan G, Taneja V and David CS. HLA class II transgenic mice mimic human inflammatory diseases. Adv Immunol. 2008; 97:65-147. | Article | PubMed

37. Abraham RS and David CS. Identification of HLA-class-II-restricted epitopes of autoantigens in transgenic mice. Curr Opin Immunol. 2000; 12:122-9. | Article | PubMed

38. Wormser GP, Bittker S, Cooper D, Nowakowski J, Nadelman RB and Pavia C. Comparison of the yields of blood cultures using serum or plasma from patients with early Lyme disease. J Clin Microbiol. 2000; 38:164850. | Article | PubMed Abstract | PubMed Full Text

39. Vollmer SA, Bormane A, Dinnis RE, Seelig F, Dobson AD, Aanensen DM, James MC, Donaghy M, Randolph SE, Feil EJ, Kurtenbach K and Margos G. Host migration impacts on the phylogeography of Lyme Borreliosis spirochaete species in Europe. Environ Microbiol. 2011; 13:184-92. | Article | PubMed

\section{Citation:}

Kovalchuka L, Eglite J, Zalite M, Lucenko I, Logina I, Karelis G, Viksna L and Krumina A. The frequency of HLA-DR alleles in patients with tick-borne disease from Latvia. Res J Infect Dis. 2014; 2:4. http://dx.doi.org/10.7243/2052-5958-2-4 